Some interesting Meliolaceae from Western Ghats Region of Kerala State, India

\title{
Hosagoudar $\mathrm{VB}^{*}$ and Riju MC
}

Tropical Botanic Garden and Research Institute, Palode - 695 562, Thiruvananthapuram, Kerala

Hosagoudar VB, Riju MC. 2011 - Some interesting Meliolaceae members from Western Ghats Region of Kerala State. Plant Pathology \& Quarantine 1(2), 121-129.

Seven new taxa collected from the Western Ghats region of Kerala State are described and illustrated in detail. Of these, Asteridiella scolopiae var. indica is a new variety while Irenopsis loranthicola, Meliola abdulkalamii, Meliola abri, Meliola canavaliae, Meliola dysoxyligena and Meliola premnigena are new species.

Key words - Black mildews - Asteridiella, Irenopsis - Meliola - new taxa - Kerala - India

\section{Article Information}

Received 31 August 2011

Accepted 19 September 2011

Published online 9 October 2011

*Corresponding author: Hosagoudar VB - e-mail - vbhosagoudar@rediffmail.com

\section{Introduction}

Kerala State possesses cultivated land and land with thick natural vegetation ranging from high altitude through to a vast coastal area. The region is known for biodiversity rich areas such as Silent Valley National Park, Munnar, Wayanad, etc. Numerous microfungi have been discovered from this state including a large collection of microfungi infecting plants from the Western Ghats region of Kerala State; some of these belonging to Meliolaceae are dealt with here.

\section{Methods}

Infected plant parts were collected with the twig, and preferably with reproductive parts of the host plants to facilitate identity. Field notes regarding the fungi and host plants were prepared. The collections were placed in blotters, which were then tied within a wire press. Changing to fresh blotters every day ensured their dryness. Host identities were confirmed by matching the collections with herbarium material and by consulting botanists. Natural coloured nail polish was applied to selected colonies and allowed to dry for 10-20 minutes. Fungal colonies, firmly embedded in the nail polish, were lifted from the leaf surface, gently and carefully placed on a slide with a drop of DPX. One to two drops of DPX were then gently dripped on it and a cover-glass placed carefully over it to avoid air bubbles. The slides were allowed to dry for 2-3 days to make a permanent slide. This process enables study of the fungal colonies virtually in situ.

\section{Results}

\section{Taxonomy}

Asteridiella scolopiae var. indica Hosag. et Riju var. nov.

MycoBank 563291

(Fig. 1)

Etymology - Named after India.

Differt a var. scolopiae appressoria recta vel curvula et antrorsa vel retrorsa.

Colonies epiphyllous, scattered, crustose, mostly near the leaf margins, up to $4 \mathrm{~mm}$ in diam., often confluent. Hyphae substraight to crooked, branching alternate to opposite at acute to wide angles, loosely to closely reticulate, cells $12-25 \times 7-10 \mu \mathrm{m}$. Appressoria alternate, unilateral, up to $1 \%$ opposite, antrorse, subantrorse to retrorse, $15-25 \mu \mathrm{m}$ long; stalk 


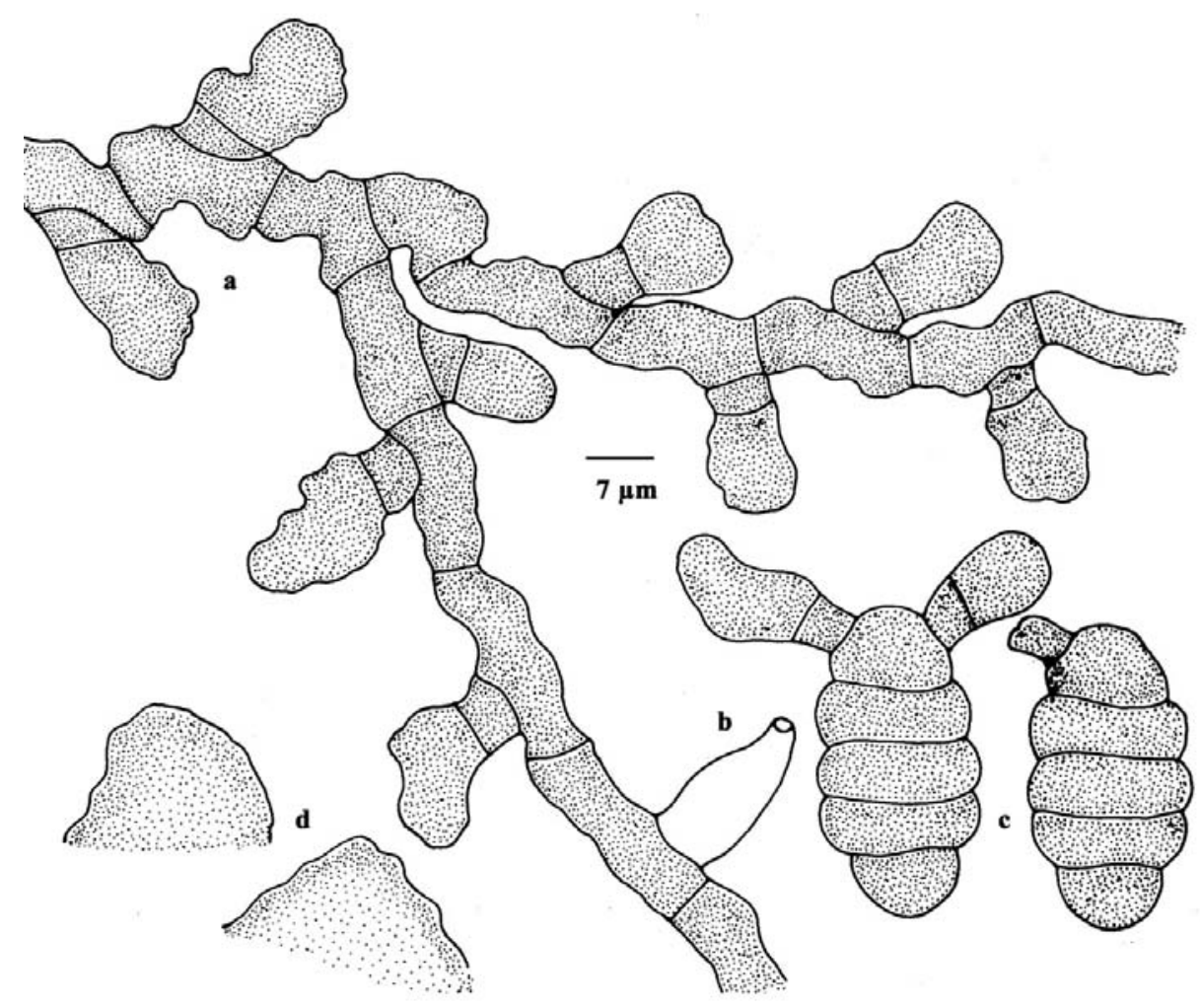

Fig. 1 - Asteridiella scolopiae var. indica var. nov. a Appressorium, b Phialide, c Ascospores, d Perithecial cells.

cells cylindrical to cuneate, 2-10 $\mu \mathrm{m}$ long; head cells ovate, oblong to cylindrical, straight to curved, entire to angular, 10-15 × 7-10 $\mu \mathrm{m}$. Phialides mixed with appressoria, ampulliform, 17-23 × 7-8 $\mu \mathrm{m}$. Perithecia scattered, up to $145 \mu \mathrm{m}$ in diam.; perithecial wall cells conoid to mammiform, straight to curved, 12-15 $\times 22-$ $28 \mu \mathrm{m}$; ascospores oblong, 4-septate, slightly constricted at the septa, 35-43 × 15-18 $\mu \mathrm{m}$.

Material examined - India, Kerala, Pathanamthitta, Sabarigiri project area, on leaves of Scolopia sp. (Flacourtiaceae), 10 January 2007, M.C. Riju \& al. TBGT 5066 (holotype). Part of the collection has been deposited in HCIO, New Delhi.

The new variety differs from the var. scolopiae Hosag. in having appressoria straight to curved and antrorse to retrorse (Hosagoudar 1996).

Irenopsis loranthicola Hosag. et Riju sp. nov.

\section{MycoBank 563292}

(Fig. 2)

Etymology - The specific epithet is derived from the host genus.

Coloniae epiphyllae, densae, velutinae, ad $3 \mathrm{~mm}$ diam., saepe confluentes. Hyphae subrectae, flexuosae vel anfractuae, oppositae acuteque vel laxe ramosae, laxe vel arte reticulatae, cellulae 15-23 × 5-8 $\mu \mathrm{m}$. Appressoria alternata vel unilateralis, antrorsa, subantrorsa vel retrorsa, 12-20 $\mu \mathrm{m}$ longa; cellulae basilares cylindraceae vel cuneatae, 2-7 $\mu \mathrm{m}$ longae; cellulae apicales plerumque integrae, ovatae, clavatae vel cylindraceae, raro angularis vel sublobatae, $10-13 \times 10-13 \mu \mathrm{m}$. Phialides appressoriis mixtus, oppositae, alternatae vel unilateralis, ampulliformes, $12-18 \times 5-8 \mu \mathrm{m}$. Perithecia dispersa, ad $130 \mu \mathrm{m}$ diam.; setae peritheciales 2-10 numero, simplices, rectae vel uncinatae ad portionio apicalis, acutae vel obtusae ad apicem, ad $185 \mu \mathrm{m}$ longae; ascosporae cylindraceae vel oblongae, 4-septatae, leniter constrictus ad septatae, 37-48 × 11-18 $\mu \mathrm{m}$.

Colonies epiphyllous, dense, velvety, up to $3 \mathrm{~mm}$ in diam., often confluent. Hyphae substraight, flexuous to crooked, branching opposite at acute to wide angles, loosely to closely reticulate, cells 15-23 × 5-8 $\mu \mathrm{m}$. Appressoria alternate to unilateral, antrorse, subantrorse to retrorse, $12-20 \mu \mathrm{m}$ long; stalk cells cylindrical to cuneate, $2-7 \mu \mathrm{m}$ long; head cells mostly entire, ovate, clavate to cylindrical, rarely angular 


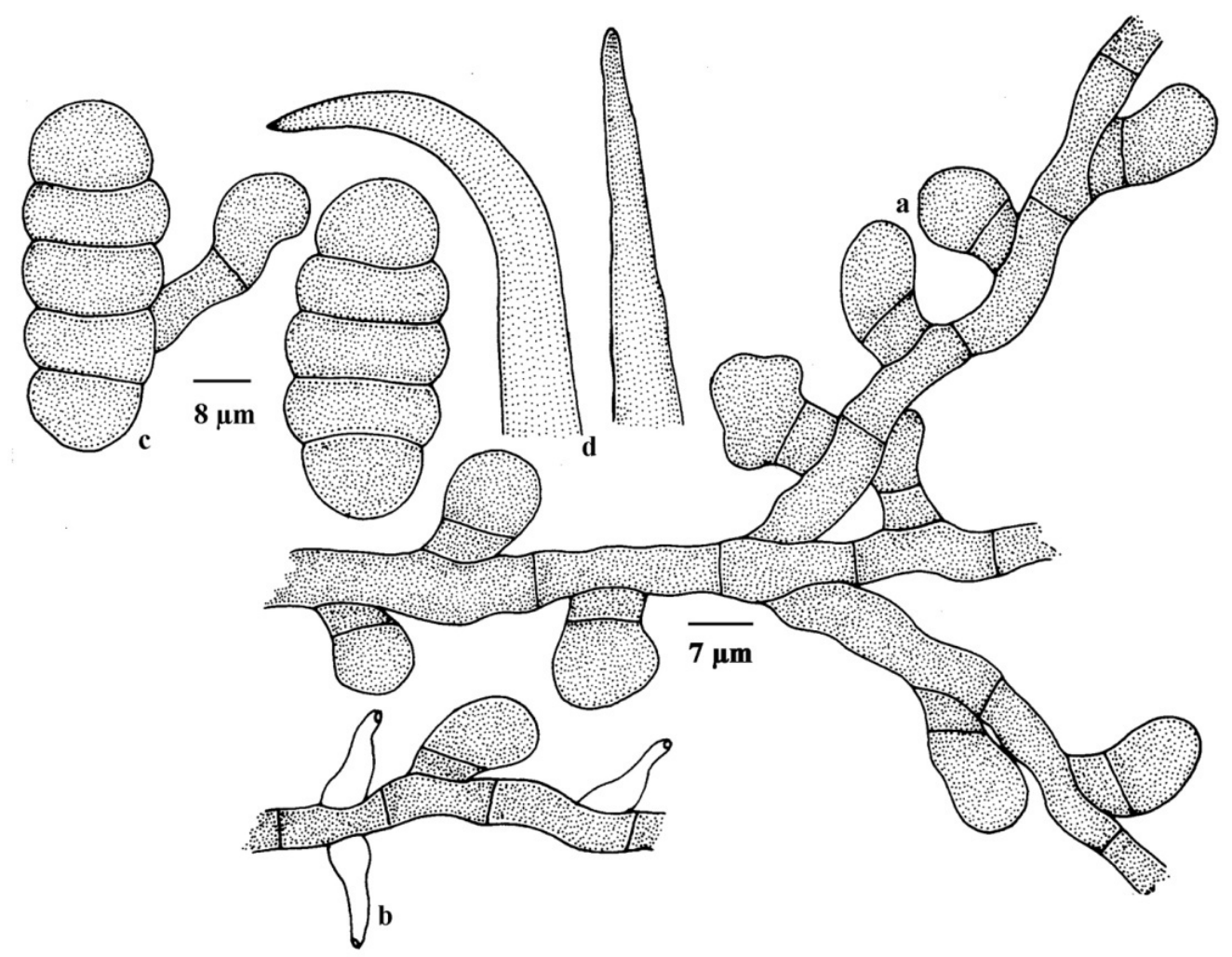

Fig. 2 - Irenopsis loranthicola sp. nov. a Appressorium, b Phialide, c Ascospores, d Perithecial setae.

to sublobate, $10-13 \times 10-13 \mu \mathrm{m}$. Phialides mixed with appressoria, opposite, alternate to unilateral, ampulliform, 12-18 × 5-8 $\mu \mathrm{m}$. Perithecia scattered, up to $130 \mu \mathrm{m}$ in diam.; perithecial setae 2-10 in number, simple, straight to uncinate at the apical portion, acute to obtuse at the tip, up to $185 \mu \mathrm{m}$ long; ascospores cylindrical to oblong, 4-septate, slightly constricted at the septa, 37-48 $\times 11-18 \mu \mathrm{m}$.

Material examined - India, Kerala, Kollam, Chozhiakode, on leaves of Loranthus sp. (Loranthaceae), 3 January 2011, V.B. Hosagoudar \& al. TBGT 5068 (holotype). Part of the collection has been deposited in HCIO, New Delhi.

This collection showed much variation in the ascospores measurements. Many Meliola species are known on members of the family Loranthaceae but the present fungus differs from the genus Meliola in having perithecial setae. Hence, it has been accommodated in a new species of Irenopsis (Hansford 1961, Hosagoudar 1996, 2008, Hu et al. 1996, 1999).

The colonies of Irenoposis loranthi were associated with Meliola loranthacearum Hosag. \& Abraham, M. prataprajii Hosag. \& Abraham and Asterina deightonii Sydow.
Meliola abdulkalamii Hosag. et Riju sp. nov.

MycoBank 563293

(Fig. 3)

Etymology - The species is named in honour of Dr. A.P.J. Abdul Kalam, former president of India, who devoted his life to science.

Coloniae epiphyllae, crustosae, ad $5 \mathrm{~mm}$ diam., dispersae, confluentes. Hyphae rectae vel flexuosae, opposite acuteque vel laxe ramosae, laxe vel arte reticulatae, cellulae 20-33 $\times$ 5-8 $\mu \mathrm{m}$. Appressoria alternata, unilateralis, antrorsa vel subantrorsa, 17-20 $\mu \mathrm{m}$ longa; cellulae basilares cylindraceae vel cuneatae, $5-8 \mu \mathrm{m}$ longae; cellulae apicales globosae, subglobosae, integrae, 7-10 × 7-13 $\mu \mathrm{m}$. Phialides apressoriis mixtus, plerumque oppositae, raro alternatae, ampulliformes, $12-18 \times 7-8 \mu \mathrm{m}$. Setae myceliales simplices, rectae, obtusae, clavatae, inflatae, dipressae vel bifidae ad apicem, late rotundatae ad apicem, ad $320 \mu \mathrm{m}$ longae. Perithecia ad $230 \mu \mathrm{m}$ diam.; ascosporae cylindraceae vel oblongae, 4-septatae, leniter constrictus ad septatae, $27-33 \times 10-13 \mu \mathrm{m}$.

Colonies epiphyllous, crustose, up to 5 $\mathrm{mm}$ in diam., scattered, confluent. Hyphae straight to flexuous, branching opposite at acute to wide angles, loosely to closely 


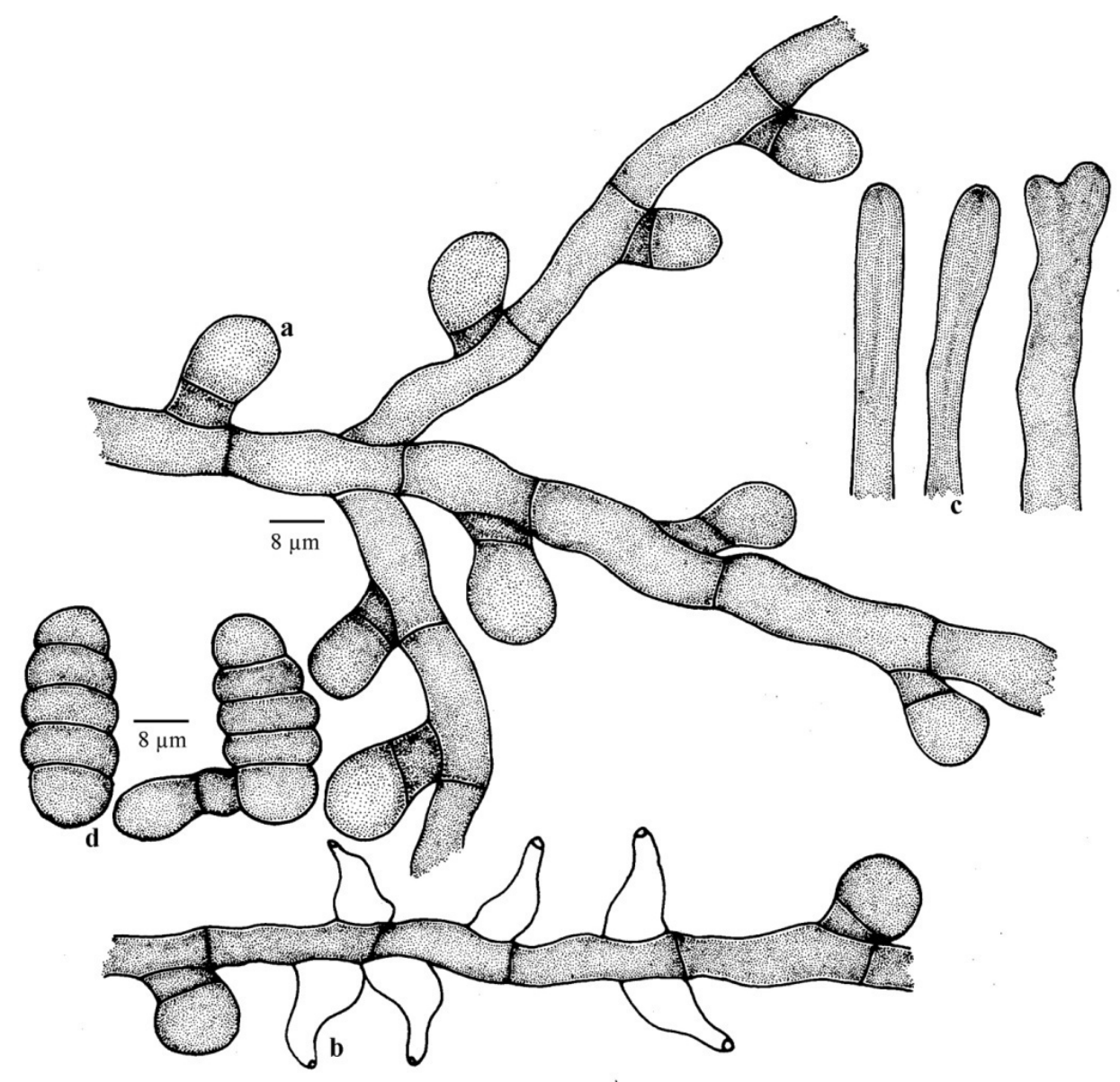

Fig. 3 - Meliola abdulkalamii sp. nov. a Appressorium, b Phialide, c Apical portion of the mycelial setae, $\mathbf{d}$ Ascospores.

reticulate, cells 20-33 × 5-8 $\mu \mathrm{m}$. Appressoria alternate, unilateral, antrorse to subantrorse, 17-20 $\mu \mathrm{m}$ long; stalk cells cylindrical to cuneate, 5-8 $\mu \mathrm{m}$ long; head cells globose, subglobose, entire, $7-10 \times 7-13 \mu \mathrm{m}$. Phialides mixed with appressoria, mostly opposite, rarely alternate, ampulliform, 12-18 × 7-8 $\mu \mathrm{m}$. Mycelial setae simple, straight, obtuse, clavate, inflated, notched to bifid at the apex, ends broadly rounded, up to $320 \mu \mathrm{m}$ long. Perithecia up to $230 \mu \mathrm{m}$ in diam.; ascospores cylindrical to oblong, 4-septate, slightly constricted at the septa, 27-33 × 10-13 $\mu \mathrm{m}$.

Material examined - India, Kerala, Wayanad, Padinharathara, 16th mile, on leaves of Aralia sp. (Araliaceae), 14 June 2009, M.C. Riju TBGT 4958 (holotype). Part of the collection has been deposited in HCIO, New Delhi.

The present species different from other Meliola species known on members of Araliaceae in having broadly obtuse, inflated to bifid tips of the mycelial setae (Hansford 1961, Hosagoudar 1996, 2008, Hu et al. 1996, 1999).
Meliola abri Hosag. et Riju sp. nov. (Fig. 4) MycoBank 56329

Etymology - The specific epithet is derived from the host genus.

Coloniae epiphyllae, tenues, dispersae, ad $3 \mathrm{~mm}$ diam. Hyphae flexuosae vel anfractuae, opposite laxe ramosae, laxe reticulatae, cellulae $17-30 \times 5-8 \mu \mathrm{m}$. Appressoria alternata vel unilateralis, ad $1 \%$ opposita, antrorsa, subantrorsa vel retrorsa, $17-20 \times 10-13 \mu \mathrm{m}$; cellulae basilares cylindraceae vel cuneatae, 2-3 $\mu \mathrm{m}$ longae; cellulae apicales globosae, ovatae, rectae vel curvulae, $12-15 \times 10-13 \mu \mathrm{m}$. Phialides appressoriis mixtus, oppositae vel unilateralis, ampulliformes, 20-25 × 5-8 $\mu \mathrm{m}$. Setae myceliales dispersae vel juxta perithecia aggregatae, simplices, rectae, acutae ad apicem, ad $360 \mu \mathrm{m}$ longae. Perithecia dispersa, ad $130 \mu \mathrm{m}$ diam.; ascosporae cylindraceae, 4-septatae, constrictus ad septatae, 30-33 × 10-13 $\mu \mathrm{m}$.

Colonies epiphyllous, thin, scattered, up to $3 \mathrm{~mm}$ in diam. Hyphae flexuous to crooked, branching opposite at wide angles, loosely 


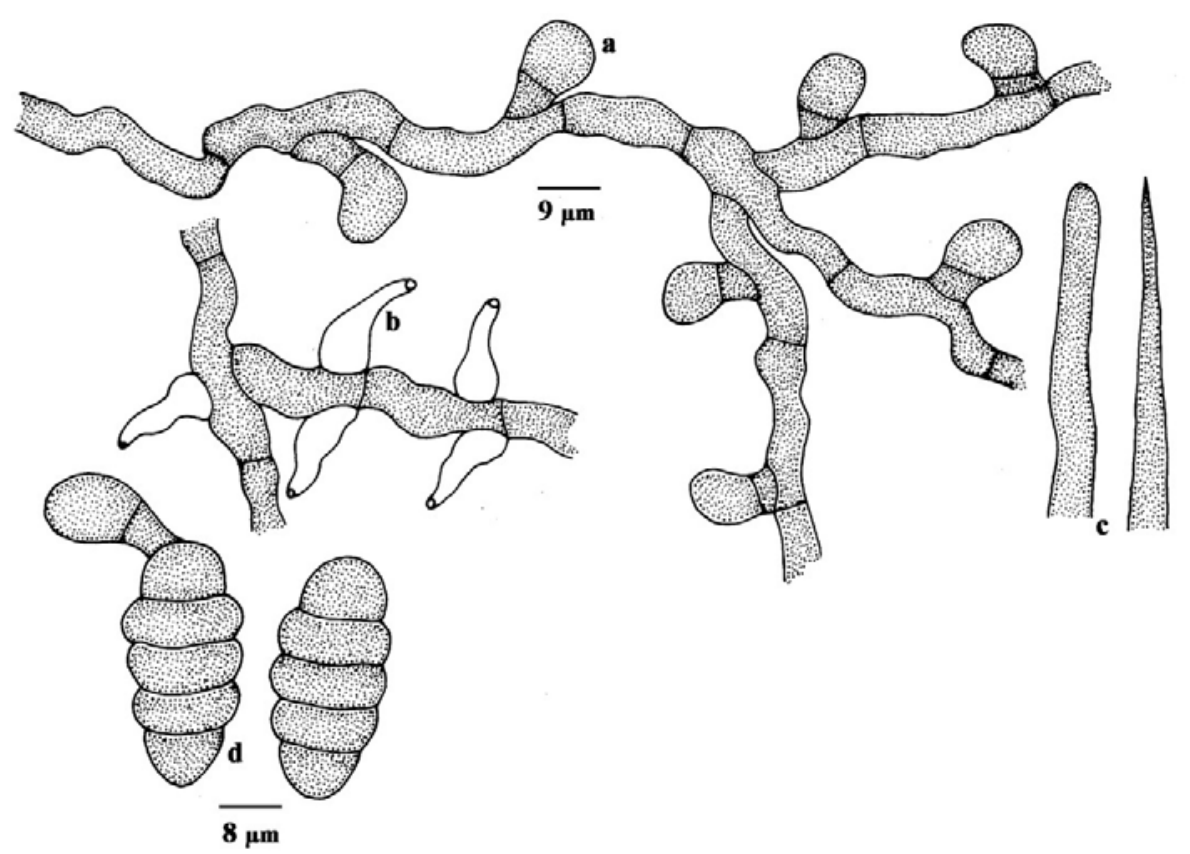

Fig. 4 - Meliola abri sp. nov. a Appressorium, b Phialide, c Apical portion of the mycelial setae, d Ascospores.

reticulate, cells $17-30 \times 5-8 \mu \mathrm{m}$. Appressoria alternate to unilateral, up to $1 \%$ opposite, antrorse, subantrorse to retrorse, $17-20 \times 10-13$ $\mu \mathrm{m}$; stalk cells cylindrical to cuneate, $2-3 \mu \mathrm{m}$ long; head cells globose, ovate, straight to curved, $12-15 \times 10-13 \mu \mathrm{m}$. Phialides mixed with appressoria, opposite to unilateral, ampuliform, 20-25 × 5-8 $\mu \mathrm{m}$. Mycelial setae scattered to grouped around perithecia, simple, straight, acute at the tip, up to $360 \mu \mathrm{m}$ long. Perithecia scattered, up to $130 \mu \mathrm{m}$ in diam.; ascospores cylindrical, 4-septate, constricted at the septa, $30-33 \times 10-13 \mu \mathrm{m}$.

Material examined - India, Kerala, Wayanad, Padinharathara, on leaves of Abrus pulchellus Wallich ex Thwaites (Fabaceae), 16 January 2011, M.C. Riju TBGT 5070 (holotype). Part of the collection has been deposited in HCIO, New Delhi.

Meliola bicornis Wint. is known on Abrus canescens from Sierra Leone (Hansford 1961), but this is a complex species and Hansford (1961) has segregated more than hundred species. Based on the simple setae and smaller ascospores, we prefer to accommodate our collection in a new species.

Meliola canavaliae Hosag. et Riju sp. nov.

MycoBank 563295
Etymology - The specific epithet is derived from the host genus.

Coloniae foliicolae, epiphyllae, tenues, dispersae, ad $4 \mathrm{~mm}$ diam. Hyphae flexuosae vel undulatae, plerumque opposite acuteque vel laxe ramosae, laxe vel arte reticulatae, cellulae 15-38 × 5-8 $\mu \mathrm{m}$. Appressoria alternata, unilateralis, raro opposita, recta vel leniter curvula, antrorsa, subantrorsa vel retrorsa, 10-18 $\mu \mathrm{m}$ longa; cellulae basilares cylindraceae vel cuneatae, 2-8 $\mu \mathrm{m}$ longa; cellulae apicales ovatae, globosae, $10-15 \times 8-15 \mu \mathrm{m}$. Phialides appressoriis mixtus, oppositae, unilateralis, ampulliformes, $15-25 \times 7-10 \mu \mathrm{m}$. Setae myceliales dispersae vel juxta perithecia aggregatae, simplices, rectae vel leniter curvulae, acutae vel obtusae ad apicem, ad $340 \mu \mathrm{m}$ longae. Perithecia dispersa, ad $160 \mu \mathrm{m}$ diam.; ascosporae cylindraceae, 4-septatae, leniter constrictus ad septatae, 33-35 × 10-13 $\mu \mathrm{m}$.

Colonies foliicolous, epiphyllous, thin, scattered, up to $4 \mathrm{~mm}$ in diam. Hyphae flexuous to undulate, branching mostly opposite at acute to wide angles, loosely to closely reticulate, cells 15-38 × 5-8 $\mu \mathrm{m}$. Appressoria alternate, unilateral, rarely opposite, straight to slightly curved, antrorse, subantrorse to retrorse, $10-18 \mu \mathrm{m}$ long; stalk cells cylindrical to cuneate, 2-8 $\mu \mathrm{m}$ long; head cells ovate, globose, $10-15 \times 8-15 \mu \mathrm{m}$. Phialides mixed with 


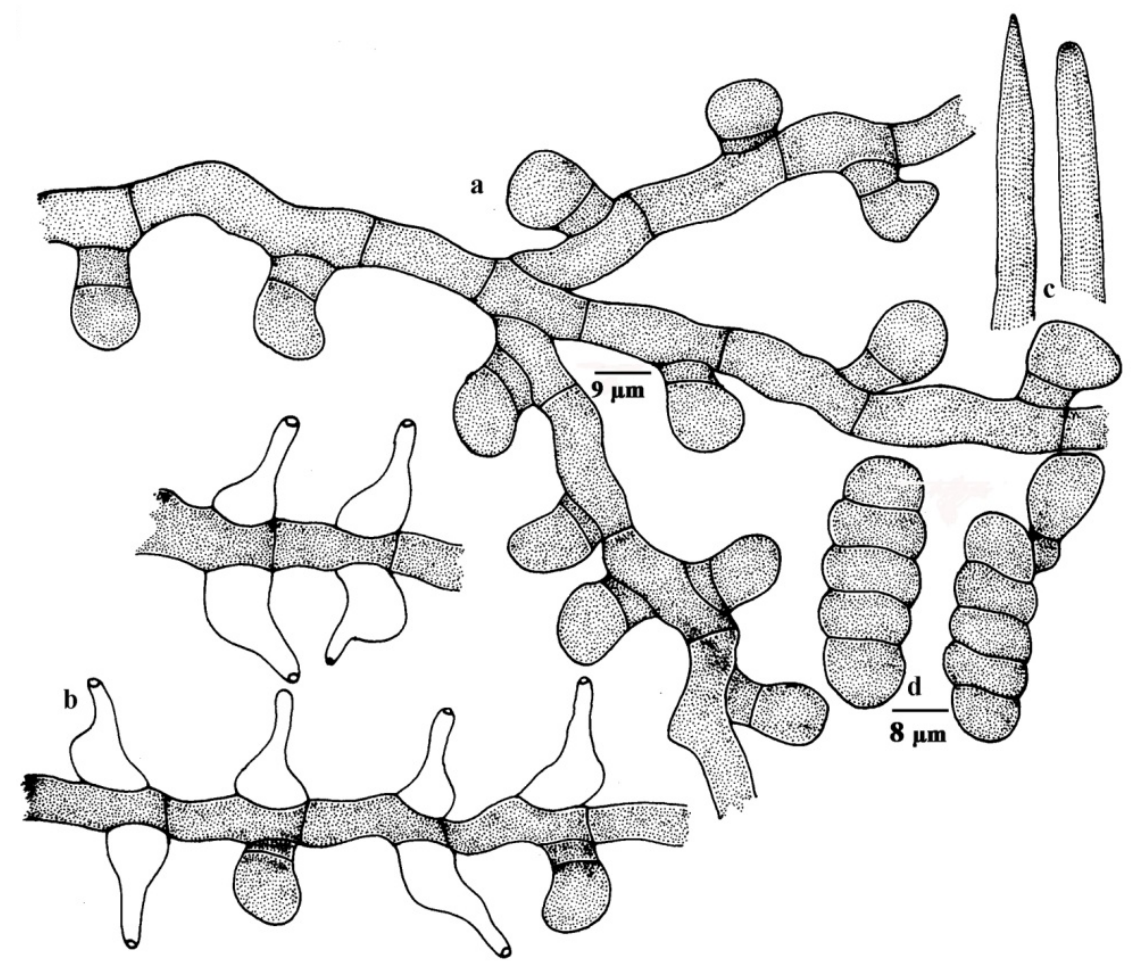

Fig. 5 - Meliola canavaliae sp. nov. a Appressorium, b Phialide, c Apical portion of the mycelial setae, d Ascospores.

appressoria, opposite, unilateral, ampulliform, 15-25 × 7-10 $\mu \mathrm{m}$. Mycelial setae scattered to grouped around perithecia, simple, straight to slightly curved, acute to obtuse at the tip, up to $340 \mu \mathrm{m}$ long. Perithecia scattered, up to 160 $\mu \mathrm{m}$ in diam.; ascospores cylindrical, 4-septate, slightly constricted at the septa, 33-35 × 10-13 $\mu \mathrm{m}$.

Material examined - India, Kerala, Wayanad, Padinharathara, $16^{\text {th }}$ mile, on leaves of Canavalia sp. (Fabaceae), 10 January 2011, M.C. Riju TBGT 4960 (holotype). Part of the collection has been deposited in HCIO, New Delhi.

Hansford (1961) identified M. teramni Sydow infecting leaves of Canavalia ensiformis collected by F.C. Deighton from Sierra Leone. The present fungus is similar but differs in having shorter (340 $\mu \mathrm{m}$ vs. $1000 \mu \mathrm{m})$, acute to obtuse setae (in contrast to 2-4 dentate or furcate) and smaller ascospores (33-35 × 10$13 \mu \mathrm{m}$ vs. $35-42 \times 13-16 \mu \mathrm{m})$.

Meliola dysoxyligena Hosag. et Riju sp. nov.

\section{MycoBank 563296}

(Fig. 6)

Etymology - The specific epithet is derived from the host genus.
Coloniae epiphyllae, densae, velutinae, ad $5 \mathrm{~mm}$ diam. Hyphae subrectae vel anfractuae, opposite vel irregulariter acuteque vel laxe ramosae, laxe vel arte reticulatae, cellulae 20-45 × 7-8 $\mu \mathrm{m}$. Appressoria alternata, unilateralis, opposita, antrorsa, subantrorsa vel retrorsa, $15-17 \times 7-10 \mu \mathrm{m}$; cellulae basilares cylindraceae vel cuneatae, 3-5 $\mu \mathrm{m}$ longae; cellulae apicales globosae, subglobosae, integrae vel raro truncatae, $10-13 \times 7-10 \mu \mathrm{m}$. Phialides appressoriis mixtus, alternatae vel oppositae, ampulliformes, $15-38 \times 7-10 \mu \mathrm{m}$. Setae myceliales dispersae, simplices, rectae, acutae-, 2-3dentatae ad apicem, ad $200 \mu \mathrm{m}$ longae. Perithecia dispersa, ad $210 \mu \mathrm{m}$ diam.; ascosporae cylindraceae vel oblongae, 4-septatae, leniter constrictus ad septatae, 35-40 × 12-15 $\mu \mathrm{m}$.

Colonies epiphyllous, dense, velvety, up to $5 \mathrm{~mm}$ in diam. Hyphae substraight to crooked, branching opposite to irregular at acute to wide angles, loosely to closely reticulate, cells 20-45 × 7-8 $\mu \mathrm{m}$. Appressoria alternate, unilateral, opposite, antrorse, subantrorse to retrorse, $15-17 \times 7-10 \mu \mathrm{m}$; stalk cells cylindrical to cuneate, 3-5 $\mu \mathrm{m}$ long; head cells globose, subglobose, entire to rarely truncate, 10-13 × 7-10 $\mu \mathrm{m}$. Phialides mixed with appressoria, alternate to opposite, ampulliform, 


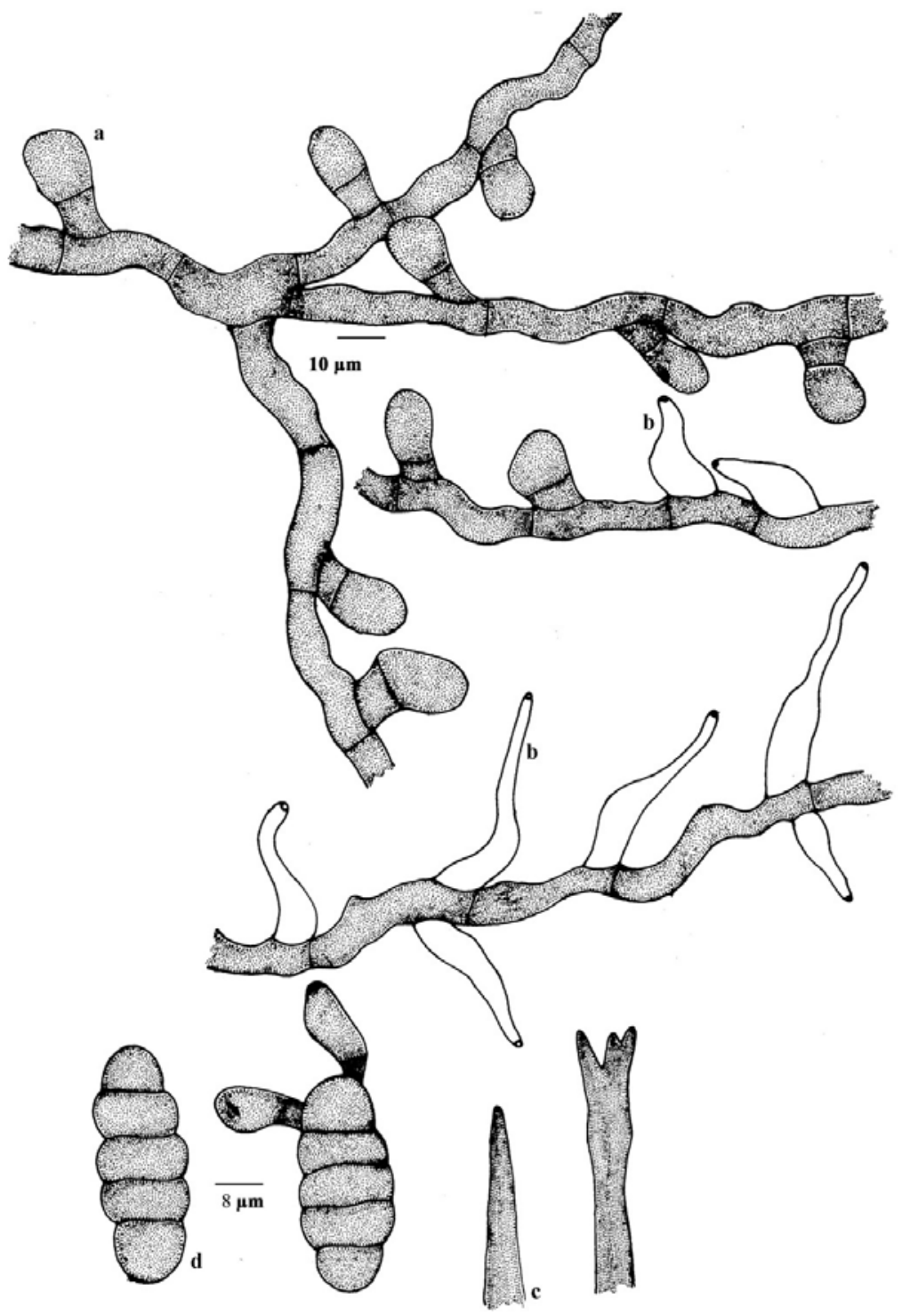

Fig. 6 - Meliola dysoxyligena sp. nov. a Appressorium, b Phialide, c Apical portion of the mycelial setae, $\mathbf{d}$ Ascospores.

15-38 × 7-10 $\mu \mathrm{m}$. Mycelial setae scattered, simple, straight, acute-, 2-3-times dentate at the tip, up to $200 \mu \mathrm{m}$ long. Perithecia scattered, up to $210 \mu \mathrm{m}$ in diam.; ascospores cylindrical to oblong, 4-septate, slightly constricted at the septa, 35-40 × 12-15 $\mu \mathrm{m}$.

Material examined - India, Kerala, Wayanad, Padinharathara, Chennalode, on leaves of Dysoxylum sp. (Meliaceae), 26 December 2009, M.C. Riju TBGT 4962 (holotype). Part of the collection has been deposited in HCIO, New Delhi.

Meliola ptaeroxyli Doidge, M. carapace Hansf. \& Deight. and M. toonae Hosag. \& Sabu are the species that have simple and dentate mycelial setae. The present fungus differs from $M$. ptaeroxyli in not producing a pathogenic effect on the host, from $M$. carapace in having shorter appressoria (15-17 $\mu \mathrm{m}$ vs. 24$40 \mu \mathrm{m})$ and smaller ascospores (35-40 × 12-15 vs. 51-58 $\times 19-23 \mu \mathrm{m})$. It differs from $M$. toonae in having shorter appressoria (15-17 $\mu \mathrm{m}$ vs. 16-24 $\mu \mathrm{m})$ and shorter ascospores (35$40 \mu \mathrm{m}$ vs. 40-44 $\mu \mathrm{m}$ ) (Hansford 1961, Hosagoudar 1996, 2008, Hu et al. 1996, 1999). The neck or apical portion of the phialides are unusually elongated, often variously bent and proliferate as hyphae by holding the phialoconidia in their neck.

Meliola premnigena Hosag. et Riju sp. nov.

MycoBank 563297

(Fig. 7)

Etymology - The specific epithet is derived from the host genus. 


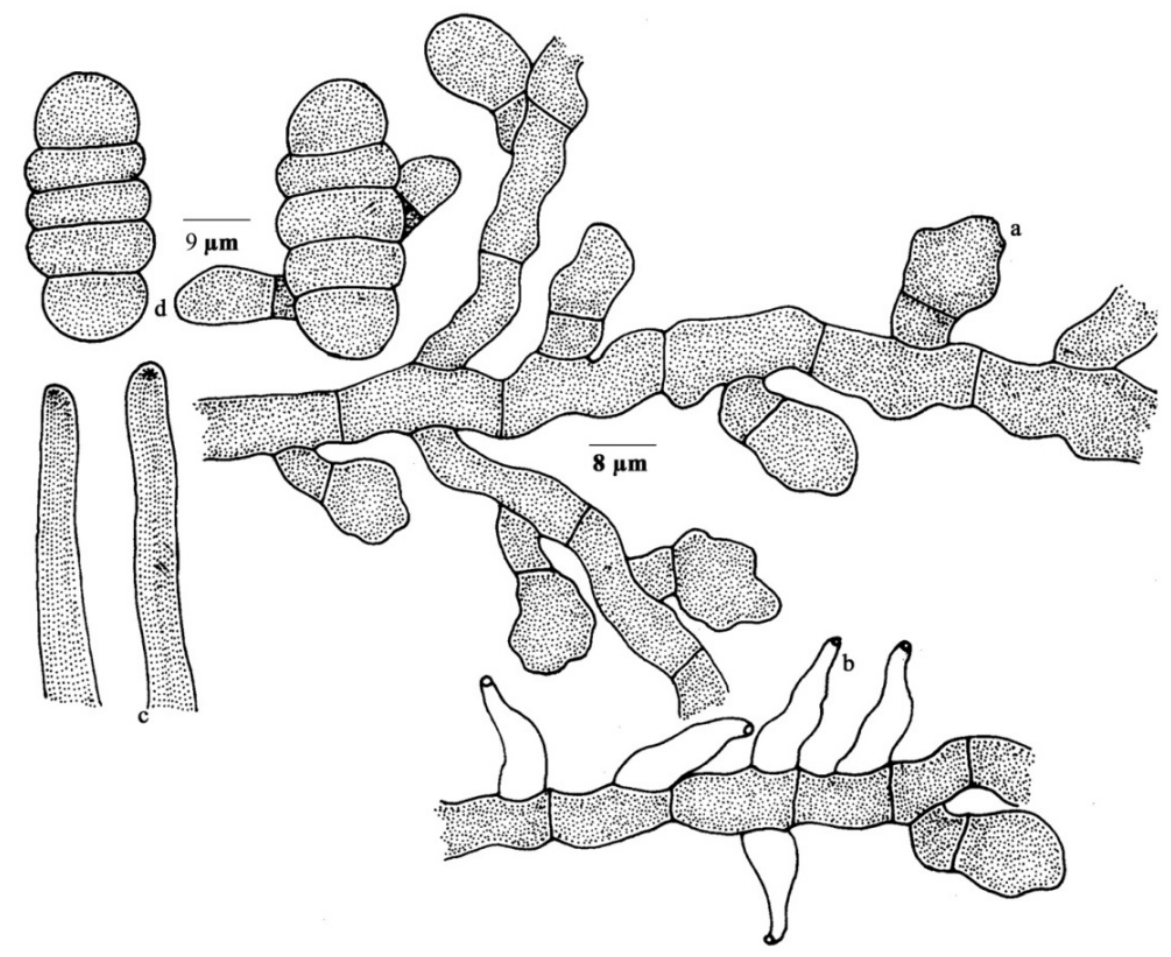

Fig. 7 - Meliola premnigena sp. nov. a Appressorium, b Phialide, c Apical portion of the mycelial setae, $\mathbf{d}$ Ascospores.

Coloniae epiphyllae, velutinae, ad $5 \mathrm{~mm}$ diam. Hyphae flexuosae vel anfractuae, opposite acuteque vel laxe ramosae, cellulae 15-25 $\times$ 5-8 $\mu \mathrm{m}$. Appressoria alternata, unilateralis, antrorsa vel subantrorsa, 15-23 $\mu \mathrm{m}$ longa; cellulae basilares cylindraceae vel cuneatae, 5$8 \mu \mathrm{m}$ longae; cellulae apicales globosae, subglobosae, integrae vel sublobatae, 10-18 × 7$13 \mu \mathrm{m}$. Phialides appressoriis mixtus, opposetae, alternatae vel unilateralis, ampulliformes, 14-23 × 4-6 $\mu \mathrm{m}$. Setae myceliales dispersae, simplices, rectae, leniter curvulae vel uncinatae, ad $300 \mu \mathrm{m}$ longae. Perithecia dispersa, ad $150 \mu \mathrm{m}$ diam.; ascosporae cylindraceae vel oblongae, 4-septatae, leniter constrictus ad septatae, $32-38 \times 12-15 \mu \mathrm{m}$.

Colonies epiphyllous, velvety, up to 5 $\mathrm{mm}$ in diam. Hyphae flexuous to crooked, branching opposite at acute to wide angles, cells $15-25 \times 5-8 \mu \mathrm{m}$. Appressoria alternate, unilateral, antrorse to subantrorse, $15-23 \mu \mathrm{m}$ long; stalk cells cylindrical to cuneate, $5-8 \mu \mathrm{m}$ long; head cells globose, subglobose, entire to sublobate, $10-18 \times 7-13 \mu \mathrm{m}$. Phialides mixed with appressoria, opposite, alternate to unilateral, ampulliform, 14-23 × 4-6 $\mu \mathrm{m}$. Mycelial setae scattered, simple, straight, slightly curved to uncinate, up to $300 \mu \mathrm{m}$ long. Perithe- cia scattered, up to $150 \mu \mathrm{m}$ in diam.; ascospores cylindrical to oblong, 4-septate, slightly constricted at the septa, 32-38 × 12-15 $\mu \mathrm{m}$.

Material examined - India, Kerala, Wayanad, Padinharathara, Banasura mala, on leaves of Premna glaberrima Wight (Verbenaceae), 10 January 2011, M.C. Riju TBGT 5069 (holotype). Part of the collection has been deposited in HCIO, New Delhi.

Based on the alternate appressoria and simple setae, this species comes close to $M$. cookeana Speg. and M. premnae Hansf. However, it differs from the former in not having inflated, dentate or furcate apex of mycelial setae. It differs from the latter in having straight hyphae and mycelial setae in contrast to flexuous, crooked, uncinate and twisted mycelial setae (Hansford 1961). It also differs from $M$. premnicola in having only obtuse mycelial setae in contrast to variously dentate ones (Hosagoudar 1996).

\section{Acknowledgement}

We thank Director, TBGRI, Palode for providing facilities and Mr. T. Shaju, TBGRI, Palode for identifying the host plants. We greatly acknowledge Dr. Mckenzie for critically reviewing the manuscript. 


\section{References}

Hansford CG. 1961 - The Meliolineae. A Monograph. Sydowia. Beihefte 2, 1-806.

Hosagoudar VB. - 1996. Meliolales of India. Botanical Survey of India, Calcutta, 363 p.

Hosagoudar VB. 2008 - Meliolales of India. Vol. II. Botanical Survey of India, Calcutta, 390 p.
Hu Y, Ouyang Y, Song B, Jiang G. 1996 Flora Fungorum Sinicorum. Vol. 4. Meliolales (1). Science Press Beijing, 270 p.

Hu Y, Song B, Ouyang Y, Jiang G. 1999 Flora Fungorum Sinicorum. Vol. 11. Meliolales (2). Science Press Beijing, 252 p. 